\title{
Current Status of Green Library Concept in Public Libraries of Central Province in Sri Lanka
}

\author{
B.N.G.S. Premarathne ${ }^{1}$ \\ B.E.S. Bandara ${ }^{2}$
}

\begin{abstract}
Green Library concept minimizes the negative effect on the natural environment and improves the quality of the library services by effective and sustainable use of resources. Concept of green library movement among the Sri Lankan library field is still at the grassroots level, whereas in the international scenario, it has already gained popularity. Therefore, the purpose of this research is to identify the current situation of green library initiatives in public libraries in Central province and to find out the level of awareness on green library concept among the library professionals. Survey research design was applied by using questionnaires. There are 193 public libraries in Central province but only 83 libraries are functioning with the Librarians Grade I, II or III. Other libraries are functioning as a reading room or branch libraries without a librarian. Total of 83 public libraries were selected purposively where there are authorized persons to manage them. The Response rate was $83 \%$. Other than that, library visits and observations are also used for the analysis. Selected public libraries are governed by the provincial local government authorities and there were different grades of librarians in each library. There are $62 \%$ adults and $38 \%$ of children are the registered user community. It was investigated that the selected libraries are fairly applying the green library concept in their libraries without knowing the green concept. They have applied this concept in the areas of waste disposal, cleaning, energy savings, gardening, natural ventilation methods and lightings in an environmental friendly way. The study found that the availability of limited land area, limited fund allocations, limited staff, administrative issues and limited resources are the barriers to create an environmental friendly library. Results concluded that the green library initiatives in public libraries of the central province are still not at in a satisfactory level. Therefore, well - planned policy is required to implement this timely important concept to Sri Lankan public libraries.
\end{abstract}

Keywords: Environment, Green library, Library service, Public libraries, Sustainable Library Development

\footnotetext{
${ }^{1}$ Library, Faculty of Dental Sciences, University of Peradeniya, Peradeniya, Sri Lanka, Email:sp12386@gmail.com

${ }^{2}$ Main Library, South Eastern University of Sri Lanka, Sri Lanka 


\section{Introduction}

Environmental challenges increase day by day as insensitive of human activities. It directly affects the economic development of the respective countries as well. It is not only affecting in monetary terms but also leading to limit the existence of all living beings.

People always focus on economic growth, employment, poverty alleviation, development of large projects to cater for rapidly increasing human wants while destroying nature. This is happening not only in the grass - root level but also in the national and international level. This ultimately resulting in polluted the environment which mainly highlighted in the fields of land degradation, poor management of water resources, impact of large-scale deforestation, loss of biodiversity, coastal erosion, scarcity of water, pollution, inadequate facilities for waste disposal and loss of agricultural productivity etc. It is timely important to address this issue in each organizational level and it is the great responsibility of each citizen of the country.

Library as a community center, also becoming important in helping communities to mobilize and organize knowledge in all aspects. Therefore, the green library concept is timely important to aware the people to protect the environment and sustainable use of the resources. A public library is an organization established, supported and funded by the community, either through local, regional or national government or through some other form of community organization (IFLA/ UNESCO Guidelines for Development, 2001). It provides access to knowledge, information resources and services to all members of the community. Resources are limited when compared to the needs and want of the community. Therefore, resources should be utilized in a sustainable manner. Poor planning of the library buildings, careless usage of the resources by the patrons, low awareness of environmentally friendly methods, not using energy - saving methods, malpractices of using resources and improper waste disposal methods are some of the key areas identified at the libraries which have an impact on the environment. Therefore, identifying the awareness and initiatives undertaken has the main impact on making policy decisions for a greener future. Hence, this research was conducted to identify the green library initiatives and identify the awareness of this concept among the staff of public libraries in Central Province, Sri Lanka

\section{Literature Review}

The Online Dictionary of Library and Information Science defines Green Library as "A library designed to minimize the negative impact on the natural environment and maximize indoor environmental quality by means of careful site selection, use of natural construction materials and biodegradable products, conservation of resources such as water, energy, paper and responsible waste disposal". 
According to Nikam (2017), there is no unique definition for the green library. Further, he stressed that the green library building must built by reducing the negative and enhancing the positive impacts while concerning the usage of natural and renewable energy sources. Hauke and Klaus (2013) stated the libraries as "gateways for knowledge" and highlighted the importance of libraries as not only for disseminating the idea of sustainability but also as a focal point to give a social message to the society. Therefore, polarizing the green concept through libraries may have a positive impact. Such small steps in going green can have a big impact on the library's image as well.

According to IFLA/UNESCO Public Library Manifesto, (1994) public library is "the local gateway to knowledge, provides the basic condition for lifelong learning, independent decision making and cultural development of the individual and social groups". Most importantly, Binks et al. (2014) stressed that sustainable library includes not only the concepts applied to library buildings, but also the processes and operations with proper procedures of a library.

It also contributes to educating the community about responsible environmental practices. Libraries are in a unique high-profile position that enables them to be community role models by implementing sustainable strategies. Since the public libraries generally deal with local communities, it has a great opportunity to be the pioneers of sustainable use of the environment. In the Sri Lankan context, the library of the Open University of Sri Lanka promotes the green concept and as a new initiative to their library, they've decided to go for solar power instead of building initiating thermal/ hydropower from the national grid (Liyanagama et al., Undated).

The Sri Lanka Army Sinha Regiment of Ambepussa has built an eco - friendly library (Sri Lanka Army, 2015). It was reported on their website as "Beating 151 competing countries, the state of the art new eco-friendly community based library, built at the Sri Lanka Sinha Regiment (SLSR) headquarters at Ambepussa was adjudged the second - best in the world, nominating it for the silver medal in the recent $4^{\text {th }}$ international eco-friendly construction competition of the 'Holcim Foundation able building concept".

\section{Objectives of the Study}

The main objective of this research was to identify the green library initiatives in public libraries in Central Province, Sri Lanka. To address this main objective, this study focused on the following specific objectives:

- Identify public libraries in the central province who have initiated this concept.

- To identify the awareness of green library concept among the librarians of public libraries in Central Province.

- To make suggestions for building green public libraries for sustainable development. 


\section{Methodology}

Study was conducted at public libraries in Central Province in Sri Lanka. The survey research design was used for the research by using questionnaires with open and closed - ended questions. There are 193 public libraries in Central province but only 83 libraries are functioning with the Librarians Grade I, II or III. Other libraries are functioning as a reading room or branch libraries without a librarian. Total numbers of selected libraries were 83 public libraries in Central Province and distributed questionnaires among them. Only 69 librarians were responded and the response rate was $83 \%$. Literature searches were used to find green library initiatives at the national and international level. In addition to the previous literature, the library visits and observations were used to identify the green initiatives in the Central Province. Descriptive analysis methods were used to analyze the data to derive the results.

\section{Results and Discussion}

\section{Background Information of the Green Initiatives in the Central Province}

This study mainly focused basically to analyze the green library initiatives in the public libraries in the central province. Out of 83 libraries selected only 69 libraries responded for the questionnaires and these libraries are governing under provincial local government authorities. There are 5 libraries in Municipal councils and all the other libraries belong to Pradeshiya sabha. That revealed the $85 \%$ of libraries are located in rural areas than in the urban areas. The green library concepts can be easily applied to these libraries by greening existing library facilities, providing green library services, and embracing environmentally supportive and sustainable practices within the library.

The registered readers' community in all libraries accounted for $62 \%$ of adults and $38 \%$ children. Library usage by the adults is higher than the children according to the responses given. Table 1 represented the key areas considered for the study.

\section{Table 1. Considered criteria for green library initiatives}

\begin{tabular}{ll}
\hline Nature of the Library Building & Disposal Method of waste \\
Nature of the Roof & 5S systems and 3R Management systems \\
Availability of Rain Gutters & Monthly Electricity Bill \\
Seating arrangements & Used Bulbs \\
Water supply & Monthly Water Bill \\
Type of Windows & Automated system \\
Area of the Land & Awareness programs \\
Cleaning &
\end{tabular}

Green libraries are often associated with green buildings, focusing on energy saving and green architecture. When considering the land area of the public libraries in the central province, they have a total land area is covering building and the garden such as 5 to 160 perches. It was noted that there is no space for gardens for most of the 
libraries and also very limited space inside the library because of the designed structure of the buildings. Many of them are old fashion buildings whereas some are newly built.

According to the results obtained 58\% of the library has an Asbestos sheet for their roofs (Table 2). These sheets may be effective for health such as long-term unsafe. According to the health reports such as the Canadian Center for Occupational Health and Safety, the Asbestos fibers are easily inhaled and carried into the lower regions of the lung where they can cause fibrotic lung disease. These diseases can lead to reduced respiratory function and death (Asbestos - Health Effects, 2012). During the day time, it generates high heat. Therefore, it requires for taking measures to reduce the heat at the noontime and it directly affects the energy consumption of the library. According to the results obtained regarding the roofing materials used for the public libraries in central province are not at a satisfactory level.

Table 2. Materials used in roof

\begin{tabular}{lc}
\hline & $\%$ \\
\hline Asbestos & 58 \\
Tile & 17 \\
Concrete & 15 \\
Aluminum Sheets & 4 \\
Steel & 4 \\
steel + Concrete & 2 \\
\hline
\end{tabular}

Considering the method of waste disposal, it can be highlighted that $52 \%$ of the public libraries, "separate and dispose" the waste from the libraries (Table 3). It is a positive fact that the public libraries in central province paid attention to discard the collected waste properly. There are neither contractors assigned for the cleaning of the libraries and nor supervisors to monitor the cleaning, except one public library. $88 \%$ of the libraries cleaning their premises daily (Table 4). Only $33 \%$ of the public libraries are using cleaning charts as to follow a proper procedure for cleaning and 26 libraries responds that they do the cleaning by themselves without hiring any person. Importantly, public libraries have less or no laborers to clean the premises.

Table 3. Waste disposal methods

\begin{tabular}{ll}
\hline & $\%$ \\
\hline Separated and remove & 52 \\
Not Separated & 12 \\
No Answer & 36 \\
\hline
\end{tabular}

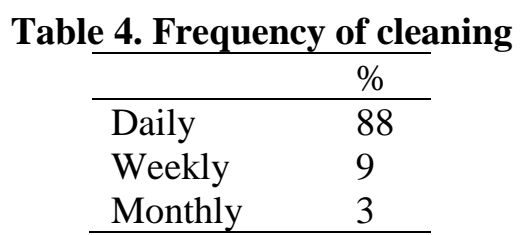

Table 5 shows that total of $83 \%$ (glass and wooden) of the libraries have small windows. It seems that the ventilation of the library has paid less attention when building them. There are many types of windows placed both inside and outside of 
the library building that affects the ventilation as well as the lighting condition for the readers.

Table 5. Types of windows used

\begin{tabular}{llr}
\hline & & $\%$ \\
\hline Small windows & Glass & 37 \\
& Wooden & 46 \\
Large windows & Steel & 3 \\
Other & & 14 \\
\hline
\end{tabular}

Maintaining of garden and fence or retaining wall also different in each other. Most of the libraries have concrete retaining wall or barbed wire and iron bar with a mesh net. If natural fences constructed of horticultural plants such as shrubbery, trees or flowering bushes, it feels attractive and aligned to the green concept, too. Table 6 shows that $81 \%$ of the public libraries have been utilized artificial fences such as barbed wires, concrete columns and meshes other than the natural fences.

Table 6. Nature of fences

\begin{tabular}{ll}
\hline & $\%$ \\
\hline Barbed wires & 29 \\
Concrete columns & 42 \\
Living fence or horticultural plants & 19 \\
Mesh & 10 \\
\hline
\end{tabular}

Energy efficiency is a major factor in the concept of green libraries. For the lighting purpose, $48 \%$ of the respondents highlighted that they are using energy- saving bulbs. Most of the libraries in the central province used LED (59\%) or CFL (23\%) bulbs to save energy. It is positive feedback received and still few of the libraries are using low efficient normal bulbs within the libraries.

Proper green procedures also have a major impact on the environment. Only 12 public libraries have the automated library systems such as Koha, Poorna, Kadiya, etc. Only 10 libraries have Internet facilities and they are using email communications and 59 libraries use the postal communications with their respective readers and posting of letters they used. Among all libraries responded, only 8 libraries use the SMS or telephone to communicate with the readers. If there is Internet facility for the remaining libraries, it may be a positive opportunity to communicate with the readers via e-mail and SMS as electronic information sharing.

$45 \%$ of the public libraries are conducting community awareness programs for their reader communities to make them aware of the environment where some libraries paid attentions to collect audio and video collections related to environment for their readers. 


\section{Suggestions for Building Green Public Libraries}

According to the open-ended questions, the public librarians have proposed the following suggestions to eye open the management. Therefore, these ideas may be useful for future planning of the libraries with the green concept.

1. Library staff should organize awareness programs for the reader community to aware the green library concept and allocate specific funds for these kinds of essential training programs.

2. There should have tree plantation programs through the "library readers" society.

3. Develop the environmental subject collection separately in all libraries

4. Library garden should be re-arranged as a green zone. Open reading area and build up the landscape with the environment - friendly way is important. Further, planting of readers attractive plants at the garden will also be useful.

5. Attitude change is essential to build up the Green Library. This is very important and the local government institutions should take initiatives.

6. IT facilities with the internet should be allocated to all libraries with the proper network system.

7. Before the establishment of any library, there should be proper planning to select a suitable location for the library building.

8. Awareness of recycling, energy saving, cleaning, water - saving, and other the environment protection programs should be introduced with essential resources.

Melanie in 2015 (cited in Hauke, 2015), developed a system rating issues like building water, transport, workflows, events and management defining sustainability criteria that might be put into practice by public libraries as in Table 7. It was designed to increase energy efficiency and reduce losses by covering all the essential areas of the green library concept with up to date technologies and processes. This system therefore, can be utilized as a good source to apply to the public libraries of Sri Lanka.

\section{Table 7. Sustainability criteria for green library}

\begin{tabular}{ll}
\hline Building & - Solar energy \\
& - Window glazing quality (thermal insulation) \\
& - Light bulb recycling: fluorescent and energy saving lamps, also \\
& LED \\
& - Structural protection from sunlight \\
& - Lighting system with movement sensors \\
& - Power supply: proportion of electricity \\
& - Lighting system with movement sensors \\
& Power supply: proportion of electricity from renewable energy \\
& Sources
\end{tabular}




\begin{tabular}{ll} 
Water & - Water saving features (wash basin equipment) \\
Transport & • Bicycle rack \\
& • Connection to public transport \\
\hline Workflows & - Waste separation \\
& - No more plastic bags \\
& - Library café: china and glass bottles instead of plastics, fair \\
& trade \\
& products \\
& - Switch off light and electronic equipment at night and in empty \\
& offices \\
& - Sustainable stationary \\
& - Ecological products for cleaning the building \\
& - Reduction of printouts \\
& - Lecycling of stationery \\
Events and & - Do-it-Yourself events and exhibitions \\
activities & Books and other materials on sustainability \\
& - Loan of e-media and appropriate readers \\
Management & "Green vision" / guidelines \\
& - Target planning in terms of "green" issues \\
& • Press work as to sustainable issues \\
& • Library staff eco-team \\
& - Further education for library staff
\end{tabular}

Further the following areas will be useful to consider the green library in the future.

1. Propose to create the "Green Corner" at the Library and several cost-effective examples of projects, exhibitions and presentations that will be helpful and knowledgeable to library patrons of all ages.

2. The library can help to protect the environment in many ways and sustainable practices within the library. The building of green library, greening existing library facilities and providing green library services.

3. Libraries are in a good position in promoting environmental awareness. Libraries can aware the society to develop ecologically sustainable practice, reusing of materials, reducing waste and toxic products and developing alternative technologies.

4. The LIS professionals can be mediate to encourage and spread the "Green library movement" in the library to their user community to protect the environment and sustainable development.

There is a wide range of ways to promote the idea of the green library. Use of environmentally friendly or recycled materials, virtual user services and resource sharing services, waste separation, elimination of plastic bags, no more paper use, 
green events and choosing library suppliers with green certificates are some of the ideas need to be popularized. Green thinking can be implemented in all areas of the library management.

\section{Conclusion}

Library professionals also have the responsibility to protect the environment and maximum use of limited resources. There should have a plan and strategies to discuss with the decision making during the planning stages of new libraries. There are different types of aspects to consider in applying of this concept.

Green concept initiatives are familiar to Sri Lankans from the past and it is therefore easy to make aware the people to initiate them for a better future. The study found that green library initiatives in public libraries of the central province are insufficient and it is still in the grass - root level. The buildings and other processes are not planned by considering the green concept and they still needs more attention. Some of the public libraries observed, practicing some of the activities without knowing that they are following the green initiatives intentionally. Some of the libraries paying a high cost for their electricity and water usages. That means their resource utilization is higher than the normal. Therefore, these areas can address according to the recommendations given herewith and to adopt green concept for respective libraries. It was identified that most libraries are not built as green buildings and library professionals have not been contributed to the building plans. The library can be role models and demonstrate to their users to protect the environment and sustainable use of the resources. Library professional can be initiated to the aware community the importance of the green library or green concept. The library reader should be an environmental - friendly person. To do that, the libraries can establish green corners, organize exhibitions, presentations, and other social activities. That should be the ultimate expectation of the green library.

\section{Reference}

Asbestos - Health Effects. (2012). Retrieved 14 March 2019, from https://www.ccohs.ca/oshanswers/chemicals/asbestos/effects.html

Binks, L., Braithwaite, E., Hogarth, L., Logan, A., \& Wilson, S. (2014). Tomorrow's green public library. The Australian Library Journal, 63(4), 301-312. doi: 10.1080/00049670.2014.969417

Hauke, P. (2015). How to become / How to identify a Green Library? Standards for Certification. In IFLA WLIC. CapeTown: IFLA. Retrieved from http://library.ifla.org/1237/1/095-hauke-en.pdf

Hauke, P., \& Werner, K. (2013). Going green as a marketing tool for libraries: environmentally sustainable management practices. In IFLA Conference. Singapore: IFLA. Retrieved from http://library.ifla.org/id/eprint/147 
IFLA/UNESCO Public Library Manifesto (1994). Retrieved 12 March 2019, from https://www.ifla.org/publications/iflaunesco-public-library-manifesto-1994

IFLA/ UNESCO Guidelines for Development (2001). International Federation of Library Associations and Institutions.

Liyanagama, J., Seneviratne, W., \& Balasooriya, A. Green Library Project (GLP): a strategic energy saving solution for the library, Open University of Sri Lanka using solar power. Open University of Sri Lanka.

New Eco-Friendly Library in Sinha Regiment Hqrs Wins Silver in Switzerland Beating 151 Countries | Sri Lanka Army. (2015). Retrieved 24 April 2019, from Nikam https://www.army.lk/news/new-eco-friendly-library-sinha-regimenthqrs-wins-silver-switzerland-beating-151-countries

Nikam, S. (2017). Green library: an emerging concept. Knowledge Librarian, 4(6), 190-198. Retrieved from http://www.klibjlis.com/4.6.20.pdf 